\title{
Intra and Inter-Population Morphological Variation of Chrysichthys nigrodigitatus Stocks in the Ebrié Lagoon (Côte d'Ivoire)
}

\author{
Benjamin Kiffôpan M'BARI' ${ }^{*}$, Moustapha DIABY ${ }^{2}$, Koffi Mexmin KONAN , Abouo Béatrice \\ ADEPO-GOURENE ${ }^{4}$ \\ ${ }^{l}$ Department of Agro-pastoral Management Institute, Laboratory of Biology, Production and Animal Health, \\ Peleforo Gon Coulibaly University, Korhogo, Côte d'Ivoire \\ ${ }^{2}$ Department of Agro-pastoral Management Institute, Peleforo Gon Coulibaly University, Korhogo, Côte \\ d'Ivoire.
}

${ }^{3}$ Department of Sciences and Environment Management, Nangui-Abrogoua University, Abidjan, Côte d'Ivoire.

${ }^{4}$ Department of Nature Sciences, Nangui-Abrogoua University, Abidjan, Côte d'Ivoire.

*Corresponding Author : Benjamin Kiffôpan M'BARI, Department of Agro-pastoral Management Institute, Laboratory of Biology, Production and Animal Health, PeleforoGonCoulibalyUniversity, Korhogo, Côte d'Ivoire

\begin{abstract}
In the Ebrié Lagoon, located in the south of Côte d'Ivoire, the exploitation of the Chrysichthysnigrodigitatus by fish farmers looking for juveniles is a threat to the sustainability of this species. The morphological diversity of this specie has therefore been analyzed in three areas of this lagoon. So, 30 metric characters on 152 specimens (51 from Layo, 50 from Aghien and 51 from Biétry Bay) were measured using a $0.05 \mathrm{~mm}$ precision MITUTOYO vernier caliper.Data processing used elementary statistics, one-way analysis of variance and multivariate analysis (Principal Component Analysis, Discriminant Factorial Analysis and Hierarchical Classification Analysis of Mahalanobis). The results obtained reveal a phenotypic homogeneity of Aghien and Layo populations and a phenotypic heterogeneity of Biétry's population. An important morphological divergence was observed between the different populations, particularly at the body heightand the anal fin length. Aghien's specimens are smaller in size,Layo's specimens are the largest. This segregation is confirmed by the discriminant analysis which gives a correct classification percentage of the Layo population's at 100\%and 98\% for Aghien's population. All of the morphological differences found are evidence of phenotypic plasticity in Chrysichthysnigrodigitatus, which would facilitate its adaptation in different environments.
\end{abstract}

Keywords: Morphological variations, populations, Chrysichthysnigrodigitatus, Ebrié Lagoon ABBREVIATIONS: Sqkm: Square kilimeter- C. nigrodigitatus: Chrysichthysnigrodigitatus- mm: millimeter.

\section{INTRODUCTION}

Southern Côte d'Ivoire has large lagoon areas long exploited for fishing [1]. Among the species sought is a silver catfish named Chrysichthysnigrodigitatus. Its intensive exploitation because of its great market value favored its domestication for its breeding. This domestication in the early 1980s left much hope for the development of brackish water fish farming. Its success has allowed, between 1981 and 1995, to regularly increase its annual national production to 300 tons ([2], [1]). Unfortunately, during the next decade, this production decreased to 20 tons per year [3], due to low fry availability [4]. To solve this production constraint, many fish farmers are sourcing juveniles directly from the natural spawning areas. This practice amplifies the intense exploitation of this species during its reproductive period, thus threatening its survival [5].

The preservation of the stock of a fish species necessarily depends on a better knowledge of its biology, in particular the structure of its population [6]. This can be studied from the analysis of morphological characters, which is a method used to characterize different fish populations ([7], [8]). This work on the morphological diversity of $C$. nigrodigitatus in the Ebrié lagoon was carried out in this context. It aims to highlight the morphological variations within and between populations of this 
species of fish present in different areas of the lagoon and to determine the morphological strategies used by this species to adapt to these environments.

\section{Material AND Methodology}

\subsection{Study Site}

The Ebrié Lagoon, with an area of $566 \mathrm{sqkm}$, is located in the south of Côte d'Ivoire between $3^{\circ} 40$ 'and $4^{\circ} 50^{\prime}$ west longitude and between $5^{\circ} 15$ 'and $5^{\circ} 20^{\prime}$ north latitude. It is $130 \mathrm{~km}$ long with a maximum width of $7 \mathrm{~km}$ and an average depth of $4.8 \mathrm{~m}$. It consists of several annex lagoons (Aghien and Potou) and bays (Biétry and Koumassi), hence its name lagoon system Ébrié [9]. The central part of the lagoon is under the influence of the Atlantic Ocean and anthropogenic discharges while the West and the East are relatively isolated from these sources (Figure 1).

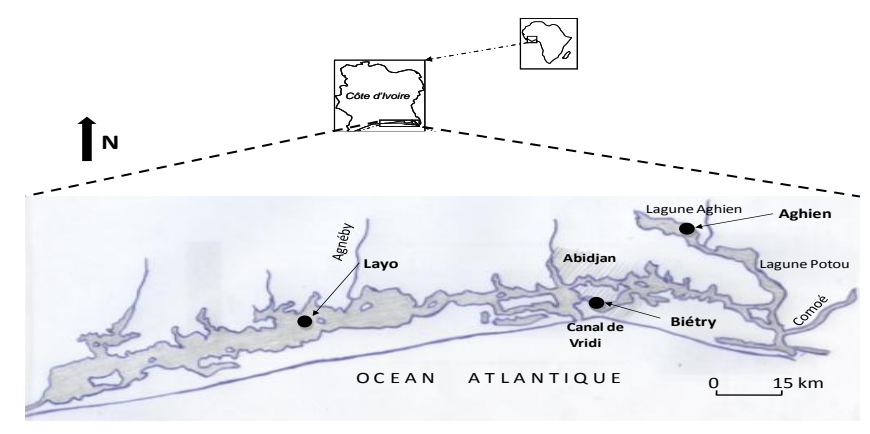

Figure1. Location of sampling sites on the Ebrié lagoon.

\subsection{Study Material}

A total of 152 specimens of Chrysichthysnigrodigitatus from the commercial fishery (51 from Layo, 50 from Aghien and 51 from Biétry Bay) were used in this work. These fish were caught using bed nets, purse seines and hawks. The specimens bear the names of the different sampling localities. Fish measurements were made using a MITUTOYO caliper $0.05 \mathrm{~mm}$ precision.

\subsection{Sampling Methods}

Sampling took place from November 2009 to January 2010. After purchase, the fish were kept in the freezer at $-4{ }^{\circ} \mathrm{C}$ for later analysis. The morphological study focused on 30 metric characters. All morphometric measurements made in millimeters on each sample were recorded in the systematic data sheet designed by Thys van den Audenaerde.

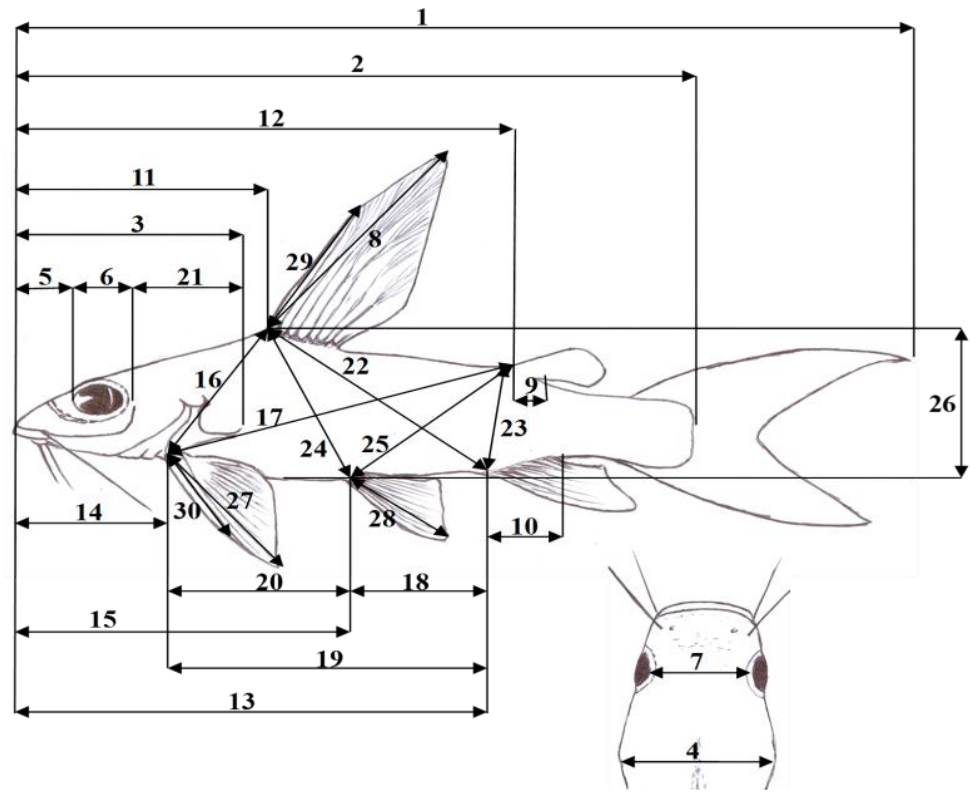

Figure2. Principal measurements taken on each Chrysichthysnigrodigitatus specimen 
Intra and Inter-Population Morphological Variation of Chrysichthys nigrodigitatus Stocks in the Ebrié Lagoon (Côte d'Ivoire)

1: total length (LT); 2: standard length (LS); 3: head length (Lte); 4: head width (LaTe); 5: muzzle length (LM); 6: eye diameter(DO); 7: interorbital distance (DIO); first dorsal fin length (LND1), 9: dorsal fin 2 length (LND2), 10: anal fin length (LNA), 11: predorsal 1length (LPrD1), 12: predorsal 2length (LPrD2) 13: preanal length (LprA); 14: prepectoral length (LPrPc); 15: prepelvic length (LPrPe); 16: dorsal pectoral length 1 (LPcD1); 17: dorsal pectoral length 2 (LPcD2); 18: pelvic anal length; (LAPe); 19: pectoral anal length (LAPc); 20: pelvic pectoral length (LPcPe); 21: operculum eye distance (OpO); 22: dorsal lanal length (LAD1); 23: dorsal 2anal length (LAD2) 24: dorsal lpelvic length (LPeD1); 25: dorsal 2pelvic length (LPeD2); 26: body height (HC); 27: pectoral fin length (LNPC); 28: pelvic fin length (LNPe); 29: dorsal spine 1length (LED1); 30: pectoral spine length $(L E P C)$.

\subsection{Data Analysis}

All morphometric data's has been standardized before being analyzed statistically.

\subsection{Standardization of Data}

Morphometric data's has been standardized to avoid size variations due to age differences between individuals of the same species ([10], [11]). All individual morphometric measurements were standardized according to the equation $\mathbf{M S}=\mathbf{M}_{\mathbf{0}}\left(\mathbf{L S} / \mathbf{L}_{\mathbf{0}}\right)^{\mathbf{b}}$ with:

MS = standardized measurement, $\mathrm{M}_{0}=$ character measurement, $\mathrm{LS}=$ mean of standard lengths of all specimens belonging to the same population and $\mathrm{L}_{0}=$ standard length of the specimen.

The value of $b$ was estimated for each character following the allometric growth equation :

$\mathbf{M}=\mathbf{a} \mathbf{L}^{\mathbf{b}}$

The parameter $b$ is the slope of the regression line of $\log _{10} \mathrm{M}_{0}$ on $\log _{10} \mathrm{~L}_{0}$ using the specimens from all groups. This parameter reveals differences between groups ([12], [13]).

\subsection{Statistical Analyzes of Metric Data}

Data processing was performed using elementary statistics, one-way analysis of variance (ANOVA 1) and multivariate analyzes. Multivariate statistics include Principal Component Analysis (PCA), Discriminant Factor Analysis (DAF) and Hierarchical Classification Analysis (ACH) based on Mahalanobis distance.

\section{RESULTS AND DISCUSSION}

\subsection{Results}

The coefficients of variation ranged from 2.38 to $43.69 \%$ in the three populations (Table I). Biétry's fish population is heterogeneous for all the metric characters studied (CV 15\%) excepted the predorsal length 2 (LPrD2), the eye diameter (OD), the head Length (Lte), head width (LaTe), pre-pectoral length (LPrPc) and dorsal-anal length 1 (LAD1). On the other hand, the other two populations studied are globally homogeneous for all the studied characters with the exception of the anal-dorsal length 2 (LAD2), the head width (LATe) and the muzzle length (LM) of Layo's specimens and pelvic-dorsal length $1(\mathrm{LPeD} 1)$ for Aghien's one.

Table 1: Results of the basic statistics of morphometric characters. Mean (Avg), Standard error (Er t), minimum and maximum value (Min - Max) and Coefficient of Variation (CV). Populations with at least one letter in common do not differ significantly. Those with no common letter differ significantly.

\begin{tabular}{|l|l|l|l|l|l|l|l|}
\hline $\begin{array}{l}\text { Variables } \\
\text { Morphometriques }\end{array}$ & Statistiques & \multicolumn{2}{l|}{ Bietry } & \multicolumn{2}{l|}{ Aghien } & \multicolumn{2}{l|}{ Layo } \\
\hline & Moy \pm Er t & $53.52 \pm$ & $0.67 \mathrm{a}$ & $41.88 \pm$ & $0.19 \mathrm{a}$ & $53.43 \pm$ & $0.87 \mathrm{a}$ \\
\hline Lte & CV & 10.79 & & 3.11 & & 11.24 & \\
\hline & Min- Max & 30.05 & 440.63 & 39.12 & 45.13 & 44.92 & 70.91 \\
\hline & Moy \pm Er t & $28.13 \pm$ & $0.52 \mathrm{a}$ & $29.82 \pm$ & $0.63 \mathrm{a}$ & $34.69 \pm$ & $0.81 \mathrm{~b}$ \\
\hline LaTe & CV & 14.24 & & 13.94 & & 16.71 & \\
\hline & Min- Max & 24.14 & 45.22 & 22.20 & 42.01 & 16.55 & 49.18 \\
\hline & Moy \pm Er t & $16.93 \pm$ & $0.40 \mathrm{a}$ & $14.88 \pm$ & $0.13 \mathrm{a}$ & $18.40 \pm$ & $0.45 \mathrm{~b}$ \\
\hline LM & CV & 16.13 & & 6.24 & & 16.89 & \\
\hline & Min- Max & 12.59 & 24.33 & 13.10 & 17.11 & 2.97 & 23.58 \\
\hline
\end{tabular}


Intra and Inter-Population Morphological Variation of Chrysichthys nigrodigitatus Stocks in the Ebrié Lagoon (Côte d'Ivoire)

\begin{tabular}{|c|c|c|c|c|c|c|c|}
\hline & Moy \pm Er t & $9.97 \pm$ & $0.13 \mathrm{a}$ & $10.38 \pm$ & $0.13 \mathrm{a}$ & $11.80 \pm$ & $0.18 \mathrm{~b}$ \\
\hline \multirow[t]{3}{*}{ DO } & $\mathrm{CV}$ & 8.53 & & 8.86 & & 10.63 & \\
\hline & Min- Max & 8.28 & 12.27 & 8.62 & 14.36 & 8.97 & 14.23 \\
\hline & Moy \pm Er t & $12.68 \pm$ & $0.44 \mathrm{a}$ & $11.81 \pm$ & $0.15 \mathrm{a}$ & $14.61 \pm$ & $0.30 \mathrm{~b}$ \\
\hline \multirow[t]{3}{*}{ DIO } & $\mathrm{CV}$ & 23.80 & & 8.87 & & 14.13 & \\
\hline & Min- Max & 7.48 & 27.07 & 8.69 & 13.57 & 11.53 & 20.36 \\
\hline & Moy \pm Er t & $18.58 \pm$ & $1.20 \mathrm{a}$ & $15.91 \pm$ & $0.09 \mathrm{a}$ & $21.20 \pm$ & $0.36 \mathrm{~b}$ \\
\hline \multirow[t]{3}{*}{ OpO } & $\mathrm{CV}$ & 43.69 & & 4.14 & & 11.85 & \\
\hline & Min- Max & 12.12 & 68.25 & 14.37 & 17.31 & 17.07 & 28.67 \\
\hline & Moy \pm Er t & $57.92 \pm$ & $1.32 \mathrm{a}$ & $53.15 \pm$ & $0.18 \mathrm{a}$ & $68.87 \pm$ & $1.12 \mathrm{~b}$ \\
\hline \multirow[t]{3}{*}{ LPrD1 } & $\mathrm{CV}$ & 15.40 & & 2.38 & & 11.31 & \\
\hline & Min- Max & 41.85 & 85.82 & 51.10 & 55.63 & 56.79 & 90.30 \\
\hline & Moy \pm Er t & $113.53 \pm$ & $1.07 \mathrm{a}$ & $99.95 \pm$ & $2.14 \mathrm{a}$ & $137.95 \pm$ & $2.09 \mathrm{~b}$ \\
\hline \multirow[t]{3}{*}{ LPrD2 } & $\mathrm{CV}$ & 6.40 & & 14.96 & & 10.50 & \\
\hline & Min- Max & 80.50 & 145.13 & 110.31 & 121.80 & 118.38 & 175.60 \\
\hline & Moy \pm Er t & $36.17 \pm$ & $0.74 \mathrm{a}$ & $33.07 \pm$ & $0.24 \mathrm{a}$ & $42.20 \pm$ & $0.77 \mathrm{~b}$ \\
\hline \multirow[t]{3}{*}{ LPrPc } & $\mathrm{CV}$ & 13.83 & & 5.08 & & 12.62 & \\
\hline & Min- Max & 25.89 & 50.53 & 28.12 & 39.25 & 34.08 & 56.69 \\
\hline & Moy \pm Er t & $81.05 \pm$ & $1.83 \mathrm{a}$ & $71.98 \pm$ & $0.37 \mathrm{a}$ & $97.02 \pm$ & $1.68 \mathrm{~b}$ \\
\hline \multirow[t]{3}{*}{ LPrPe } & $\mathrm{CV}$ & 15.35 & & 3.60 & & 12.00 & \\
\hline & Min- Max & 61.89 & 117.98 & 63.70 & 77.98 & 78.04 & 141.97 \\
\hline & Moy \pm Er t & $81.60 \pm$ & $2.70 \mathrm{a}$ & $73.55 \pm$ & $0.30 \mathrm{a}$ & $102.64 \pm$ & $1.50 \mathrm{~b}$ \\
\hline \multirow[t]{3}{*}{ LPcD2 } & $\mathrm{CV}$ & 22.42 & & 2.87 & & 10.12 & \\
\hline & Min- Max & 11.76 & 132.10 & 68.19 & 79.07 & 86.91 & 128.85 \\
\hline & Moy \pm Er t & $39.62 \pm$ & $0.81 \mathrm{a}$ & $42.69 \pm$ & $1.03 \mathrm{a}$ & $51.10 \pm$ & $0.82 \mathrm{a}$ \\
\hline \multirow[t]{3}{*}{ LPeD1 } & $\mathrm{CV}$ & 15.61 & & 15.79 & & 11.51 & \\
\hline & Min- Max & 33.60 & 67.26 & 30.69 & 42.99 & 41.38 & 64.60 \\
\hline & Moy \pm Er t & $44.90 \pm$ & $1.13 \mathrm{a}$ & $39.32 \pm$ & $0.35 \mathrm{a}$ & $52.15 \pm$ & $0.89 \mathrm{~b}$ \\
\hline \multirow[t]{3}{*}{ LPeD2 } & $\mathrm{CV}$ & 17.03 & & 6.25 & & 11.84 & \\
\hline & Min- Max & 33.81 & 68.67 & 33.16 & 45.81 & 30.25 & 65.48 \\
\hline & Moy \pm Er t & $66.11 \pm$ & $1.45 \mathrm{a}$ & $59.35 \pm$ & $0.25 \mathrm{a}$ & $78.02 \pm$ & $1.11 \mathrm{~b}$ \\
\hline \multirow[t]{3}{*}{ LAD1 } & $\mathrm{CV}$ & 14.93 & & 2.90 & & 9.83 & \\
\hline & Min- Max & 51.99 & 96.23 & 56.28 & 62.77 & 66.54 & 99.23 \\
\hline & Moy \pm Er t & $28.34 \pm$ & $0.70 \mathrm{a}$ & $24.55 \pm$ & $0.37 \mathrm{a}$ & $32.71 \pm$ & $0.90 \mathrm{~b}$ \\
\hline \multirow[t]{3}{*}{ LAD2 } & $\mathrm{CV}$ & 16.80 & & 10.61 & & 18.97 & \\
\hline & Min- Max & 21.15 & 40.77 & 21.61 & 39.30 & 3.80 & 51.26 \\
\hline & Moy \pm Er t & $33.52 \pm$ & $1.33 \mathrm{a}$ & $30.26 \pm$ & $0.27 \mathrm{a}$ & $37.74 \pm$ & $0.48 \mathrm{~b}$ \\
\hline \multirow[t]{3}{*}{ LAPe } & $\mathrm{CV}$ & 26.95 & & 6.25 & & 8.83 & \\
\hline & Min- Max & 24.77 & 76.79 & 25.49 & 35.22 & 31.05 & 45.26 \\
\hline & Moy \pm Er t & $79.61 \pm$ & $1.99 \mathrm{a}$ & $71.99 \pm$ & $0.35 \mathrm{a}$ & $96.65 \pm$ & $1.22 \mathrm{~b}$ \\
\hline \multirow[t]{3}{*}{ LAPc } & $\mathrm{CV}$ & 16.98 & & 3.38 & & 8.74 & \\
\hline & Min- Max & 43.69 & 118.56 & 68.39 & 80.87 & 84.05 & 119.22 \\
\hline & Moy \pm Er t & $48.99 \pm$ & $1.30 \mathrm{a}$ & $42.26 \pm$ & $0.38 \mathrm{~b}$ & $59.69 \pm$ & $0.89 \mathrm{c}$ \\
\hline \multirow[t]{3}{*}{ LPcPe } & $\mathrm{CV}$ & 18.06 & & 6.21 & & 10.33 & \\
\hline & Min- Max & 35.43 & 73.65 & 36.40 & 49.27 & 48.11 & 77.13 \\
\hline & Moy \pm Er t & $41.05 \pm$ & $1.14 \mathrm{a}$ & $35.64 \pm$ & $0.27 \mathrm{a}$ & $52.15 \pm$ & $0.84 \mathrm{~b}$ \\
\hline \multirow[t]{3}{*}{ LD1D2 } & $\mathrm{CV}$ & 18.83 & & 5.26 & & 11.15 & \\
\hline & Min- Max & 20.31 & 64.47 & 30.00 & 39.01 & 42.16 & 64.24 \\
\hline & Moy \pm Er t & $20.38 \pm$ & $0.59 \mathrm{a}$ & $19.20 \pm$ & $0.14 \mathrm{a}$ & $24.50 \pm$ & $0.38 \mathrm{~b}$ \\
\hline LND1 & $\mathrm{CV}$ & 19.56 & & 5.05 & & 10.65 & \\
\hline & Min- Max & 9.86 & 30.80 & 16.95 & 21.77 & 20.03 & 31.91 \\
\hline & Moy \pm Er t & $14.58 \pm$ & $0.68 \mathrm{a}$ & $12.19 \pm$ & $0.16 \mathrm{a}$ & $14.85 \pm$ & $0.30 \mathrm{~b}$ \\
\hline LND2 & $\mathrm{CV}$ & 31.60 & & 9.15 & & 14.18 & \\
\hline & Min- Max & 5.64 & 33.05 & 9.80 & 15.23 & 10.36 & 18.89 \\
\hline & Moy \pm Er t & $33.59 \pm$ & $0.81 \mathrm{a}$ & $31.14 \pm$ & $0.35 \mathrm{a}$ & $38.99 \pm$ & $0.75 \mathrm{~b}$ \\
\hline LNPc & $\mathrm{CV}$ & 16.45 & & 7.86 & & 13.24 & \\
\hline & Min- Max & 19.40 & 49.58 & 25.93 & 35.41 & 29.16 & 52.53 \\
\hline & Moy \pm Er t & $27.38 \pm$ & $0.68 \mathrm{a}$ & $26.23 \pm$ & $0.25 \mathrm{a}$ & $29.61 \pm$ & $0.51 \mathrm{~b}$ \\
\hline LNPe & $\mathrm{CV}$ & 16.90 & & 6.65 & & 11.94 & \\
\hline
\end{tabular}


Intra and Inter-Population Morphological Variation of Chrysichthys nigrodigitatus Stocks in the Ebrié Lagoon (Côte d'Ivoire)

\begin{tabular}{|l|l|l|l|l|l|l|l|}
\hline & Min- Max & 17.39 & 41.32 & 21.56 & 31.10 & 24.02 & 39.62 \\
\hline & Moy \pm Er t & $19.22 \pm$ & $0.72 \mathrm{a}$ & $16.15 \pm$ & $0.17 \mathrm{~b}$ & $22.27 \pm$ & $0.49 \mathrm{c}$ \\
\hline LNA & CV & 25.30 & & 7.28 & & 15.26 & \\
\hline & Min- Max & 6.69 & 33.44 & 13.68 & 19.08 & 16.58 & 29.69 \\
\hline & Moy \pm Er t & $17.63 \pm$ & $0.45 \mathrm{a}$ & $15.28 \pm$ & $0.09 \mathrm{a}$ & $21.20 \pm$ & $0.36 \mathrm{~b}$ \\
\hline LPePe & CV & 17.43 & & 4.16 & & 11.60 & \\
\hline & Min- Max & 13.03 & 26.44 & 13.44 & 17.36 & 17.43 & 28.01 \\
\hline & Moy \pm Er t & $15.59 \pm$ & $0.56 \mathrm{a}$ & $13.28 \pm$ & $0.09 \mathrm{a}$ & $17.85 \pm$ & $0.28 \mathrm{~b}$ \\
\hline HPC & CV & 24.40 & & 4.77 & & 10.81 & \\
\hline & Min- Max & 11.18 & 34.17 & 11.61 & 14.78 & 14.75 & 23.40 \\
\hline & Moy \pm Er t & $35.22 \pm$ & $0.92 \mathrm{a}$ & $28.79 \pm$ & $0.37 \mathrm{~b}$ & $37.06 \pm$ & $0.68 \mathrm{c}$ \\
\hline HC & CV & 17.65 & & 9.09 & & 12.65 & \\
\hline & Min- Max & 22.92 & 52.89 & 23.08 & 36.92 & 27.60 & 48.79 \\
\hline & Moy \pm Er t & $30.47 \pm$ & $0.82 \mathrm{a}$ & $27.70 \pm$ & $0.48 \mathrm{a}$ & $34.04 \pm$ & $0.78 \mathrm{~b}$ \\
\hline LED1 & CV & 18.23 & & 12.05 & & 15.87 & \\
\hline & Min- Max & 19.97 & 48.69 & 20.49 & 37.77 & 23.61 & 47.93 \\
\hline & Moy \pm Er t & $27.14 \pm$ & $1.03 \mathrm{a}$ & $25.48 \pm$ & $0.32 \mathrm{a}$ & $33.15 \pm$ & $0.72 \mathrm{~b}$ \\
\hline LEPc & CV & 26.95 & & 9.11 & & 15.49 & \\
\hline & Min- Max & 0.00 & 42.17 & 18.49 & 29.83 & 23.61 & 47.35 \\
\hline
\end{tabular}

The analysis of variance of morphometric characters excepted the head length (LTe) and pelvic-dorsal length 1 (LPeD1) showed a very significant difference ( $\mathrm{p}<0.001)$ between populations (Table II). The multiple comparison test indicates that populations compared in pairs are highly differentiated (Table I). Overall, all populations are statistically different at the level of predorsal length 2 (LPrD2), pelvicpelvic length (LPcPe), anal fin length (ANL), and body height (HC). For these parameters, the highest values were recorded in Layo's population specimens while the lowest values were observed in individuals from Aghien. In addition, the Layo's population discriminates from the other two populations by the other metric characters. For these descriptors, the Layo specimens always record the highest values at the head, body and fin level. However, no parameter makes it possible to differentiate individuals from Biétry from those of Aghien according to the multiple comparison tests. However, for the majority of these parameters, Biétry's population specimens display higher values than those recorded on Aghien's specimens.

Table2. Results of Variance Analysis of Metrics. ***: Highly Significant Difference and NS: Not Significant

\begin{tabular}{|c|c|c|c|c|c|}
\hline Variables & SC Effet & dl Effet & MC Effet & $\mathrm{F}$ & $\mathrm{p}$ \\
\hline LS & 72320,1 & 2 & 36160,07 & 38,4894 & $* * *$ \\
\hline Lte & 4332,0 & 2 & 2166,01 & 1,9286 & NS \\
\hline LaTe & 1231,2 & 2 & 615,58 & 33,2052 & $* * *$ \\
\hline LM & 302,7 & 2 & 151,34 & 25,5088 & $* * *$ \\
\hline DO & 87,4 & 2 & 43,69 & 41,5838 & $* * *$ \\
\hline DIO & 198,2 & 2 & 99,10 & 20,9273 & $* * *$ \\
\hline OpO & 678,4 & 2 & 339,18 & 14,4706 & $* * *$ \\
\hline LPrD1 & 6273,5 & 2 & 3136,73 & 67,4374 & $* * *$ \\
\hline LPrD2 & 35859,4 & 2 & 17929,69 & 109,2696 & $* * *$ \\
\hline LPrPc & 2086,0 & 2 & 1043,00 & 56,2465 & $* * *$ \\
\hline LPrPe & 15550,4 & 2 & 7775,20 & 79,7011 & $* * *$ \\
\hline LPrA & 28351,4 & 2 & 14175,69 & 70,4264 & $* * *$ \\
\hline LPcD1 & 2134,8 & 2 & 1067,41 & 67,5071 & $* * *$ \\
\hline LPcD2 & 21773,2 & 2 & 10886,62 & 74,8950 & $* * *$ \\
\hline LPeD1 & 187666,6 & 2 & 93833,28 & 1,0776 & NS \\
\hline LPeD2 & 4012,5 & 2 & 2006,23 & 59,5901 & $* * *$ \\
\hline LAD1 & 8643,8 & 2 & 4321,89 & 83,0430 & $* * *$ \\
\hline LAD2 & 1617,1 & 2 & 808,53 & 35,8828 & $* * *$ \\
\hline LAPe & 1361,9 & 2 & 680,96 & 21,8357 & $* * *$ \\
\hline LAPc & 15400,8 & 2 & 7700,39 & 90,8800 & $* * *$ \\
\hline LPcPe & 7475,4 & 2 & 3737,70 & 92,7845 & $* * *$ \\
\hline LD1D2 & 6842,9 & 2 & 3421,46 & 107,6763 & $* * *$ \\
\hline LND1 & 746,0 & 2 & 373,01 & 48,3178 & $* * *$ \\
\hline
\end{tabular}


Intra and Inter-Population Morphological Variation of Chrysichthys nigrodigitatus Stocks in the Ebrié Lagoon (Côte d'Ivoire)

\begin{tabular}{|c|c|c|c|c|c|}
\hline LND2 & 206,9 & 2 & 103,44 & 11,8372 & $* * *$ \\
\hline LNPc & 1558,1 & 2 & 779,06 & 37,4383 & $* * *$ \\
\hline LNPe & 286,5 & 2 & 143,24 & 11,8135 & $* * *$ \\
\hline LNA & 907,3 & 2 & 453,65 & 37,9491 & $* * *$ \\
\hline LPePe & 861,8 & 2 & 430,90 & 82,8157 & $* * *$ \\
\hline HPC & 504,4 & 2 & 252,22 & 41,7948 & $* * *$ \\
\hline HC & 1831,1 & 2 & 915,55 & 41,3383 & $* * *$ \\
\hline LED1 & 978,7 & 2 & 489,37 & 20,7896 & $* * *$ \\
\hline LEPc & 1667,4 & 2 & 833,72 & 29,6766 & $* * *$ \\
\hline
\end{tabular}

\subsubsection{Differentiation of Populations by the Principal Component Analysis (PCA)}

The Principal component analysis of all the data collected was done by retaining only the axes expressing an eigenvalue equal or greater than 0.8. In the first 3 axes thus selected, only the first two axes were considered in the ordination analysis because they represent alone $83.43 \%$ of the total variability (Table III). The correlations of the different variables to the first three axes are shown in Table IV. Only the first axis contributes significantly to the discrimination of the three groups. Indeed, all the descriptors are strongly correlated to this factorial axis excepted the length of the first spine of thefirst dorsal fin (LE1D1), the head length (LTe) and the interorbital distance (DIO). On the other hand, the last two descriptors cited are strongly correlated with the factorial axis 2 . As for the factorial axis 3 , it is only correlated with LE1D1. All these descriptors are positively correlated with these axes.

Table3. Eigenvalues with variance percentage of the first three axes in the PCA.

\begin{tabular}{|l|l|l|l|}
\hline Axis & Eigenvalues & \% Total variance & $\%$ Cumulative variance \\
\hline 1 & 24,42 & 78,79 & 78,79 \\
\hline 2 & 1,44 & 4,64 & 83,43 \\
\hline 3 & 0,84 & 2,71 & 86,14 \\
\hline
\end{tabular}

Table4. Factorial weights of the metric variables on the first three axes.

\begin{tabular}{|l|l|l|l|}
\hline Variables & Axe 1 & Axe 2 & Axe 3 \\
\hline Lte & 0,04 & 0,91 & 0,02 \\
\hline LaTe & 0,90 & 0,18 & 0,04 \\
\hline LM & 0,78 & 0,25 & 0,02 \\
\hline DO & 0,71 & 0,13 & 0,12 \\
\hline DIO & 0,65 & 0,29 & 0,12 \\
\hline OpO & 0,96 & 0,14 & 0,04 \\
\hline LPrD1 & 0,98 & 0,16 & 0,02 \\
\hline LPrD2 & 0,84 & 0,17 & 0,01 \\
\hline LPrPc & 0,95 & 0,16 & $-0,01$ \\
\hline LPrPe & 0,97 & 0,16 & 0,02 \\
\hline LPrA & 0,97 & 0,16 & 0,02 \\
\hline LPcD1 & 0,96 & 0,18 & 0,01 \\
\hline LPcD2 & 0,96 & 0,20 & 0,04 \\
\hline LPeD1 & $-0,03$ & 0,01 & $-0,99$ \\
\hline LPeD2 & 0,88 & 0,22 & 0,03 \\
\hline LAD1 & 0,97 & 0,19 & 0,04 \\
\hline LAD2 & 0,82 & 0,24 & 0,07 \\
\hline LAPe & 0,87 & 0,15 & 0,06 \\
\hline LAPc & 0,96 & 0,18 & 0,03 \\
\hline LPcPe & 0,93 & 0,17 & 0,02 \\
\hline LD1D2 & 0,93 & 0,17 & 0,06 \\
\hline
\end{tabular}

The projection of the individuals on the factorial axes 1 and 2 (Figure 3), shows the very clear separation of the population of Layo from that of Aghien. However, a large overlap is observed between the polygons of individuals from Layo and Biétry. Moreover, the last mentioned polygon completely covers that of the individuals of Aghien. The point clouds for the specimens from Layo and Biétry are located on either side of the positive and negative coordinates of the factorial axes 1 and 2. No parameter really contributes to the orientation of these specimens. However, it should be noted that the scatterplot polygon for specimens from Biétry completely covers that of the Aghien 
Intra and Inter-Population Morphological Variation of Chrysichthys nigrodigitatus Stocks in the Ebrié Lagoon (Côte d'Ivoire)

sample and largely that of Layo. On the other hand, the specimens of Aghien are on both sides negative coordinates of factorial axis 2 . This orientation seems to be governed by all the characters strongly correlated with the factorial axis 1.

\subsubsection{Differentiation of Populations by the Discriminant Factor Analysis (DFA)}

The correct classification matrix obtained from the Discriminant Factor Analysis shows that $97.37 \%$ of the specimens studied belong to their original group (Table V). The DFA recognized all 51 specimens collected in Layo as originating from this locality while 2 individuals from Biétry Bay were reclassified in Aghien's group and 1 in Layo's one. In fish collected in Aghien'sarea, only 1 individual was attached by the test to Biétry's fishes group.

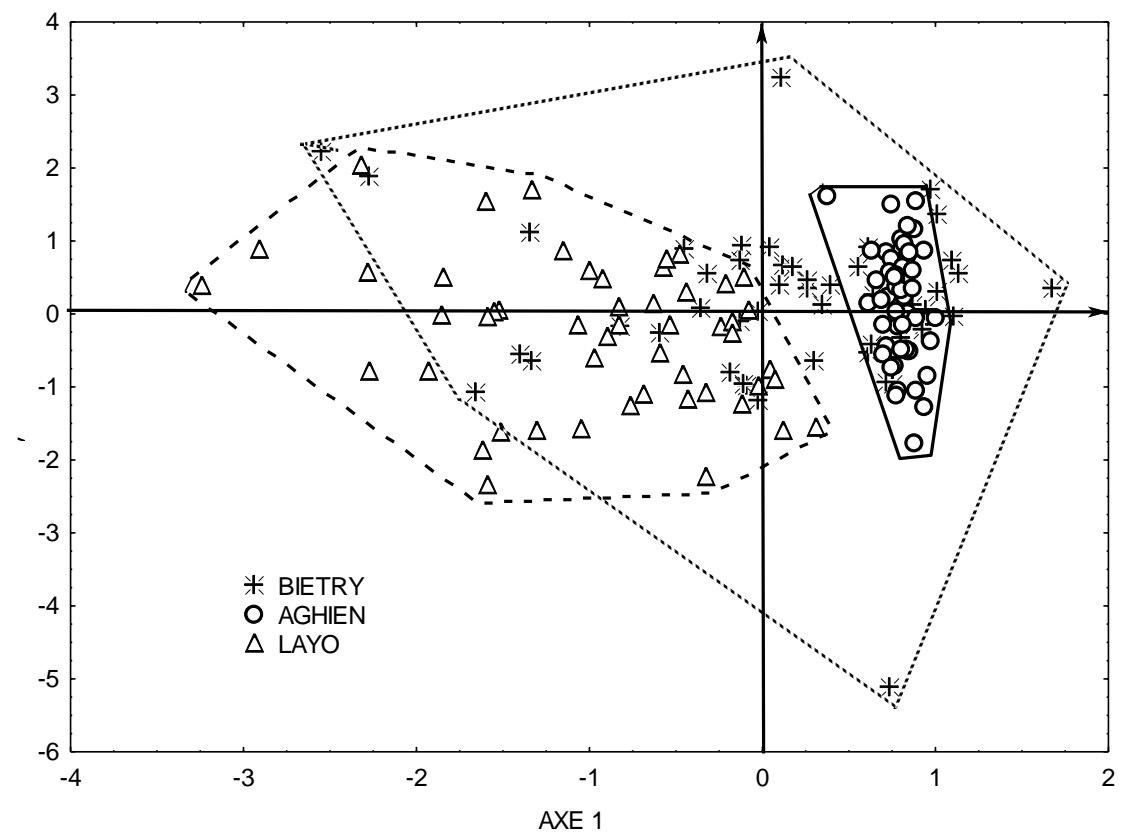

Figure3. Projection of $C$. nigrodigitatus populations in the factorial axis 1 and 2 of morphometric parameters' $P C A$.

Table5. Percentage of individuals reclassified in each group, in the validation of the DFA for the morphometric data.

\begin{tabular}{|l|l|l|l|l|l|}
\hline Localities & $\begin{array}{l}\text { Pourcentage de } \\
\text { classification correcte }\end{array}$ & AGHIEN & BIETRY & LAYO & Total \\
\hline AGHIEN & $98 \%$ & 49 & 1 & 0 & 50 \\
\hline BIETRY & $94,12 \%$ & 2 & 48 & 1 & 51 \\
\hline LAYO & $100 \%$ & 0 & 0 & 51 & 51 \\
\hline Total & $\mathbf{9 7 , 3 7 \%}$ & $\mathbf{5 1}$ & $\mathbf{4 9}$ & $\mathbf{5 2}$ & $\mathbf{1 5 2}$ \\
\hline
\end{tabular}

Moreover, of the 30 characters expressing a variability between the different populations according to the ANOVA, 8 descriptors were identified as the most discriminating $(\mathrm{p} \leq 0.05)$ by the $\lambda$-Wilk test (Table VI). This is by order of the increasing discriminatory power of the pelvic fin length ( $\mathrm{LNPe}$ ), the pre-dorsal distance 2 (LPrD2), the body height (HC), the head width (LaTe), the eye diameter (OD), the dorsal fin 1 length (LND1), the pectoral spine length (LEPc) and the anal fin length (LNA).

Table6. $p$ ( $p$-level) values of the different variables after the Lambda Wilk test.

\begin{tabular}{|l|l|l|l|l|}
\hline Variables & $\boldsymbol{\lambda}$ Wilk & $\boldsymbol{F}$ & $\boldsymbol{d}$ & $\boldsymbol{P}$ \\
\hline LNPe & 0,82 & 13,28 & 2 & $* * *$ \\
\hline LPrD2 & 0,85 & 10,57 & 2 & $* * *$ \\
\hline HC & 0,87 & 8,92 & 2 & $* * *$ \\
\hline LaTe & 0,90 & 6,43 & 2 & $* *$ \\
\hline DO & 0,90 & 5,98 & 2 & $* *$ \\
\hline LND1 & 0,93 & 4,63 & 2 & $*$ \\
\hline LEPc & 0,94 & 4,01 & 2 & $*$ \\
\hline LNA & 0,94 & 3,68 & 2 & $*$ \\
\hline
\end{tabular}


The ordination of the 3 populations in the plane formed by the canonical axes showed a sharper distribution of the three populations studied than the PCA (Figure 4).

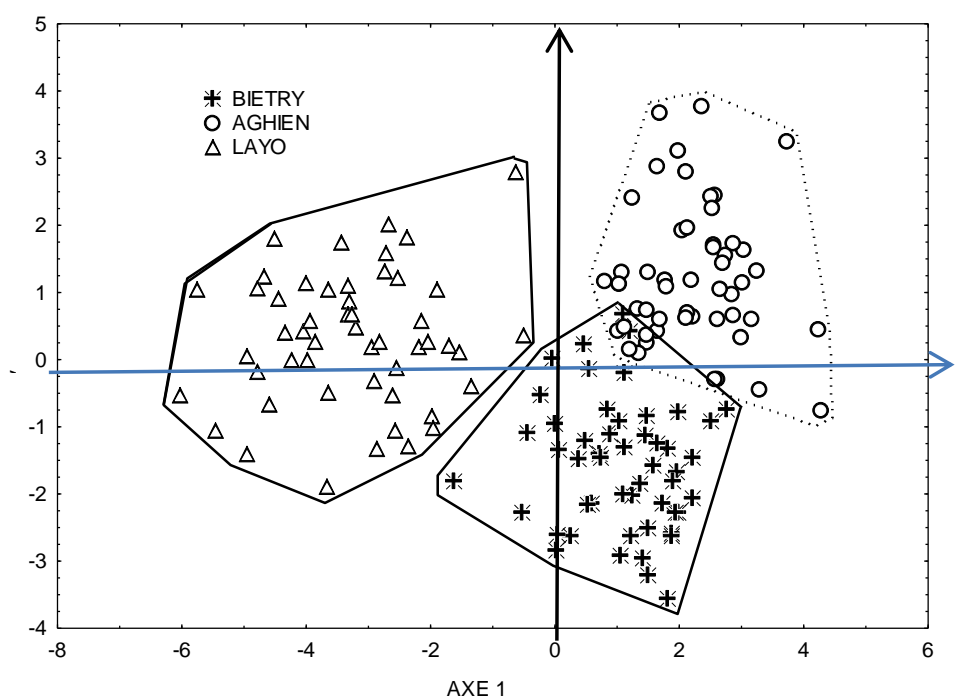

Figure4. Distribution of the different populations in the DFA canonical plans 1 \& 2 according to metric descriptors.

According to this representation based on the $\lambda$-Wilk test results, the population of Layo is clearly distinct from the two others. On the other hand, a slight overlap is observed between the polygons representing Biétry's population and Aghien's one. The Biétry's specimens are mainly located in the zone formed by the positive coordinates of the canonical axis 1 and the negative coordinates of the canonical axis 2 while those of Aghien, are mainly oriented in the plane formed by the positive coordinates of the two canonical axes.

The Mahalanobis distance estimated between the different populations studied was demonstrated using the Ward aggregation method (Table VII). The largest distance (21.06) separates the samples from the bays of Biétry and Layo. In addition, the distance between Layo and Aghien (13.48) is also relatively high. The lowest distance is obtained between Biétry and Aghien (5.61). All these distances between these populations are statistically significant $(\mathrm{p}<0.001)$.

Table7. Distances of Mahalanobis between the 3 populations studied.

\begin{tabular}{|l|l|l|l|}
\hline Populations & AGHIEN & BIETRY & LAYO \\
\hline AGHIEN & - & - & - \\
\hline BIETRY & 5,61 & - & - \\
\hline LAYO & 13,48 & 21,06 & - \\
\hline
\end{tabular}

The dendrogram resulting from the ascending hierarchical classification revealed 2 population groups at aggregation distance 42 (Figure 5). Group I consists of the populations of Biétry Bay and Aghien. Group II consists solely of Layo population's.

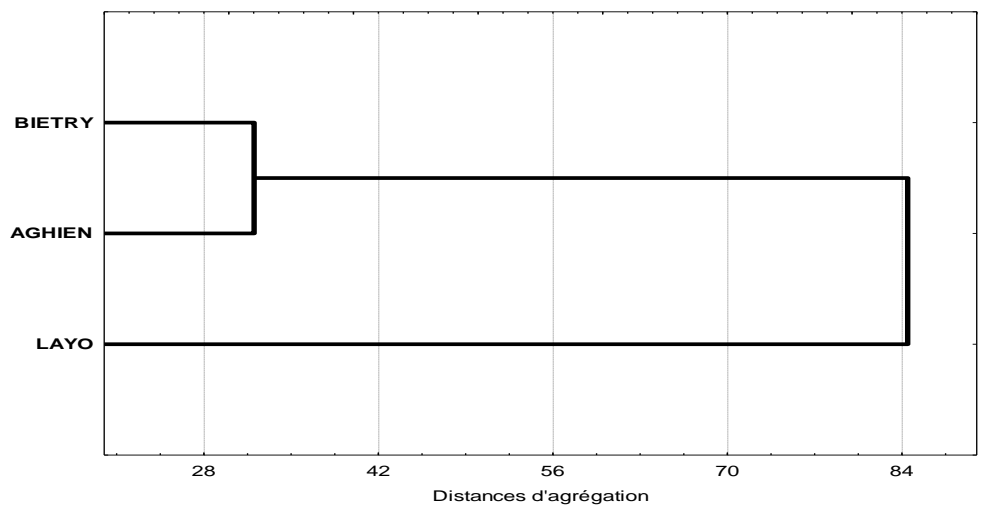

Figure5. Dendrogram of the three populations according to Ward's method. 


\section{DISCUSSION}

The results of univariate and multivariate statistics performed on the metric descriptors selected in this study showed very remarkable morphometric variability between the three populations of Chrysichthysnigrodigitatus. Elementary statistics revealed low coefficients of variation for almost all variables measured in Aghien's and Layo's specimens (CV <15\%). They each constitute a phenotypically homogeneous group. This could be explained by their perfect adaptation to their respective environments and attest to the impact of the environment on the establishment of different phenotypes. In other words, each population seems to have developed a typical morphology in relation to its environment. The reference [14] supports this idea by arguing that low values of coefficient of variation of biometric parameters indicate strong heritability and, consequently, the limited influence of environmental variations on morphological variability. Variance analysis revealed that all morphometric parameters vary from one population to another with the exception of head length (LTe) and pelvic-dorsal length 1 (LPeD1). As a result, these descriptors could be considered as key ecological traits related to the habitat of these fish populations.

On the other hand, the phenotypic heterogeneity observed within the Biétry Bay population is seems to be the consequence of an individual adaptation of the different specimens to the environmental conditions of this area. Bietry bay is characterized by very strong intra-annual and spatial environmental variations. This hypothesis is supported by reference [15] and [16] who argue that phenotypic heterogeneity within a fish population is an adaptive response of some individuals to environmental variation. This intra-populational phenotypic plasticity is the result of an interaction between environmental and genetic factors [17], whereas according to reference [18], only environmental conditions are responsible of it. In addition, several studies show that morphological traits may reflect certain ecological or behavioral characteristics of fish ([19], [20]), which mitigates the effects of environmental variation. Such phenotypic adaptations do not necessarily result from genetic changes in populations.

All of the morphological differences found are evidence of phenotypic plasticity in Chrysichthysnigrodigitatus, which would facilitate its adaptation to environmental conditions and survive in different environments. Reference [21] and [22] argue that the phenotypic plasticity of fish allows them to adapt to environmental changes through changes in their physiology and behavior, resulting in changes in their morphology, reproduction or survival.

There is a very important morphological divergence between the different populations. Indeed, the Aghien specimens are characterized by smaller sizes while Layo's individuals are larger. This strong dissimilarity between the specimens of these two populations could be explained by the fact that the Aghien site and the Layo site, although all belonging to the lagoon complex Ebrié, are isolated from each other. There seems to be little or no exchange of individuals between them. This strong segregation is confirmed by the discriminant analysis which gives a correct classification percentage of $100 \%$ for Layo's population and $98 \%$ for the population of Aghien. Reference [23] explains the morphometric variability between populations of different sites by the distinct genetic structure or environmental conditions in each area.

It should be noted that in terms of the environment, the Layo and Aghien sites are characterized by their relative physico-chemical stability [24]. Each of these environments has its own characteristic. In addition, Biétry's Bay has a hydrological cycle marked by strong spatio-temporal variations. These variations are due to oceanic and fluvial influences on this environment. These variations would force individuals to constantly adapt to these changes [25].

\section{CONCLUSiON}

The present study evaluated the morphological variability between three populations of Chrysichthysnigrodigitatus of Ebrié lagoon. Phenotypic homogeneity of the Aghien and Layo populations and phenotypic heterogeneity of the Biétry's population are noted. Moreover, the existence of a phenotypic plasticity within C. nigrodigitatus has been revealed. This phenotypic plasticity could be a strategy of adaptation to the different environmental conditions that prevail in the environments studied. A very important morphological divergence is observed between the different populations in particular at the body height and the anal fin length. Aghien's specimens are smaller in size while Layo's are larger and Biétry's are in intermediate sizes between the other two. 
The Ebrié Lagoon is constituted by several environments, some of which are the subject to intense variations to which populations of $C$. nigrodigitatus are subject. It would therefore be necessary to approach several lines of research in order to better understand the relationship between the species and its different environments.

\section{REFERENCES}

[1] Hem S.,Nuñez Rodriguez J. (1995).L'aquaculture du Mâchoiron(Chrysichthysnigrodigitatus, (Lacépède, 1803)) en Côte d'Ivoire : Un exemple de recherche pour le développement. In : Biodiversité et Aquaculture en Afrique, Rapport final de l'atelier d'Abidjan, 21/25 Novembre 1994,21-23.

[2] OuattaraM., Kouakou K.,GourèneG. (1993).Une approche technologique peu onéreuse de production de larves et d'alevins de Chrysichthysnigrodigitatus (Pisces; Bagridae). Agronomie africaine, 1, 33-38.

[3] FAO(2005).Les productions en ressources halieutiques de la Côte d'Ivoire. Aperçu général du secteur national d'aquaculture-Côte d'Ivoire. [Online] Available : http://www.fao.org/fi/website/MultiQuery Action.do (18-12-2007).

[4] PangniK., AtséB.C. KouassiN.J. (2008).Influence of broodstock age on reproductive success in the african catfishChrysichthysnigrodigitatus(ClaroteidaeLacépede, 1803). Research Journal of Animal Sciences, 2(5):139-143.

[5] HemS. (1986). Premiers résultats sur la reproduction contrôlée deChrysichthysnigrodigitatus en milieu d'élevage.In : Aquaculture Research in the Africa Region, Proc Afr. Sem. Aquacult. Organised by IFS, October 1985, PUDOC, Wageningen (Hollande), 189-205.

[6] CarvalhoG.R.,HausserL. (1992). Species changes in African lakes: Genetic impacts of fish introductions and exploitation.Consultancy report to Impact of Species Changes in African Lakes Project, MRAG Ltd., vol. $62,229 \mathrm{p}$.

[7] MarquesJ. F., Teixeira C.M.,CabralH.N. (2006). Differentiation of commercially important flatfish populations along the Portuguese coast: Evidence from morphology and parasitology. Fisheries Research, 81, 293-305.

[8] FerritoV., ManninoM.C., Pappalardo A.M.,TiganoC.(2007).Morphological variation among populations of AphaniusfasciatusNardo, 1827 (Teleostei, Cyprinodontidae) from the Mediterranean.Journal of Fish Biology, 70, 1-20.

[9] TastetJ.-P. (1971). Le contexte géologique du site d'Abidjan. Annales de l'Université d'Abidjan, Série G, tome III, 225-246.

[10] TuranC., ErgüdenD., Turan F.,GürlekM. (2004). Genetic and Morphologic Structure of Liza abu (Heckel, 1843) Populations from the Rivers Orontes, Euphrates and Tigris.Turk J. Vet. Anim. Sci., 28, 729-734.

[11] KuhajdaB.R., MaydenR.L,WoodR.M. (2007). Morphological comparisons of hatchery-reared specimens of Scaphirhynchusalbus, $S$. platorynchus, and $S$. albus $\times S$. platorynchus hybrids (Acipenseriformes:Acipenseridae). J. Appl. Ichthyol., 23, 324-347.

[12] ElliottN.G., HaskardK.,KoslowJ.A. (1995). Morphometric analysis of orange roughy (Hoplostethusatlanticus) of the continental slope of southern Australia.Jounal of Fish Biology, 46, 202220.

[13] LleonartJ., SalatJ.,TorresG.J. (2000). Removing allometric effects of body size of morphological analysis. J. Theor. Biol., 205, 85-93.

[14] MamurisZ., ApostolidisA.P., PanagiotakiP., TheodorouA.J.,TriantaphyllidisC. (1998). Morphological variation between red mullet populations in Greece.Journal of Fish Biology,52, 107-117.

[15] GrandjeanF., RomainD., Avila-ZarzaC., BramardM., Souty-Grosset C.,MocquardJ. P. (1997). Morphometry, sexual dimorphism and size at maturity of the white-clawed crayfish Austropotamobiuspallipepallipe (Lereboullet) from a wild French population at Deux-Sèvres (Decapoda, Astacidae).Crustaceana, 70(1):31-44.

[16] SardaF., BasC.,RoldánM. I., Pla C.,LleonartJ. (1998). Enzymatic and morphometric analyses in Mediterranean populations of the rose shrimp, Aristeusantennatus (Risso, 1986). Journal of Experimental Marine Biology and Ecology, 22, 131-144.

[17] MurtaA.G. (2000). Morphological variation of horse mackerel (Trachurustrachurus) in the Iberian and North Africa Atlantic: implications for stock identification.ICES Journal of Marine Science, 57, 12401248.

[18] ClaytonJ.W. (1981).The stock concept and the uncoupling of organismal and molecular evolution. Canadian Journal of Fisheries and Aquatic Sciences, 38, 1515-1522. 
[19] HjelmJ., PerssonL.,ChristensenB. (2000).Growth, morphological variation and ontogenetic niche shifts in perch (Percafluviatilis) in relation to resource availability.Oecologia, 122, 190-199.

[20] SchilewenU., RassmannK., MarkmannM., MarkertJ., Kocher T..TautzD. (2001).Genetic and ecological divergence of a monophyletic cichlid species pair under fully sympatric conditions in Lake Ejagham, Cameroon.Molecular Ecology,10,1471-1488.

[21] StearnsS.C. (1983).A natural experiment in life-history evolution: field data on the introduction of mosquitofish (Gambusiaaffinis) to Hawaii.Evolution, 37,601-617.

[22] MeyerE. (1987). Phenotypic plasticity and heterochromy in Cichlasomamanguense(Pisces: Cichlidae) and their implications for speciation in cichlid fish.Evolution, 41, 1357-1369.

[23] KinseyS.T., OrsoyT., Bert T.M.,MahmoudiB. (1994). Population structure of the Spanish sardine Sardinellaaurita: Natural morphological variation in a genetically homogenous population.Mar. Biol., 118, 309-317.

[24] DufourP., AlbaretJ.J., Durand J.R.,GuiralD. (1994). Fonctionnement de l'écosystème Ebrié.In : Environnement et ressources aquatiques de Côte d'Ivoire, Tome II, Les milieux lagunaires, Durand, J. R., Dufour, P., Guiral,D. and Zabi, S. G. F. (Eds.), ORSTOM, 509-526.

[25] ArfiR., GuiralD.,Torreton J.P. (1989).Cycle hydrologique annuel d'une baie lagunaire eutrophe : la baie de Biétri (lagune Ebrié, Côte d'ivoire). Rév. Hydrobiol. Trop., 22(4): 263-273.

Citation: Benjamin Kiffôpan M'BARI, et.al, "Intra and Inter-Population Morphological Variation of Chrysichthys nigrodigitatus Stocks in the Ebrié Lagoon (Côte d'Ivoire)". International Journal of Innovative Studies in Aquatic Biology and Fisheries, 5(3), pp.1-11.http://dx.doi.org/10.20431/2454-7670.0503001

Copyright: (C) 2019 Authors. This is an open-access article distributed under the terms of the Creative Commons Attribution License, which permits unrestricted use, distribution, and reproduction in any medium, provided the original author and source are credited. 